\title{
Acute Hepatic Coma Successfully Treated by Extracorporeal Baboon Liver Perfusions
}

\author{
G. M. ABOUNA, L. McA. FISHER, W. J. STILL, D. M. HUME
}

British Medical fournal, 1972, 1, 23-25

\section{Summary}

Two patients in deep hepatic coma due to fulminant viral hepatitis were treated by extracorporeal baboon liver perfusion after failing to respond to medical treatment and three consecutive exchange transfusions. Both patients recovered full consciousness after one liver perfusion, made a complete recovery, and were leading normal lives seven and eight months after treatment. Perfusions were maintained for $13 \frac{1}{2}$ and $16 \frac{1}{2}$ hours without complication, and neither clinical immunological reactions nor antibaboon serum antibodies developed as a result of treatment.

Whereas normal consciousness could be restored only by liver perfusion, both exchange transfusion and liver perfusion were effective in clearing bilirubin and in raising the level of clotting factors. Extracorporeal baboon liver perfusion provides a safe and effective method for the treatment of acute hepatic coma.

\section{Introduction}

The management of hepatic coma due to acute hepatic necrosis remains one of the difficult problems in clinical medicine at the present time.

In recent years a variety of extracorporeal hepatic support techniques have been used for the treatment of this condition (Berger et al., 1966; Eiseman et al., 1966; Starzl et al., 1966; Burnell et al., 1967; Jones et al., 1967; Abouna et al. 1969; Hume et al., 1969; Condon et al., 1970) and of these exchange blood transfusion and pig liver perfusion have had the widest clinical application. However, neither of these techniques has by itself proved satisfactory and, in the absence of a controlled study, their exact role in the treatment of hepatic failure has been difficult to define (Benhamou et al., 1968; Williams, 1971).

We report here an effective method for the treatment of hepatic coma with extracorporeal baboon liver perfusion. This method was used successfully in the treatment of two patients with fulminant viral hepatitis who had failed to respond to medical treatment and repeated exchange blood transfusions.

\section{Patients and Techniques}

The two patients treated were females who developed grade IV hepatic coma as a result of fulminant viral hepatitis. On admission to hospital a standard medical treatment was instituted which included withdrawal of dietary protein, colonic lavage, oral neomycin, multivitamins, glucose infusions, and corticosteroids. When the level of consciousness continued to deteriorate and grade IV coma supervened despite intensive medical therapy

\footnotetext{
Department of Surgery, Medical College of Georgia, Augusta, Georgia 30902, U.S.A.

G. M. ABOUNA, M.B., F.R.c.s., Assistant Professor of Surgery

Virginia Commonwealth University, Richmond, Virginia, U.S.A. L. MCA. FISHER, M.D., PH.D., Professor of Haematology

W. J. STILL, M.D., Professor of Pathology

D. M. HUME, M.D., Professor of Surgery
}

exchange blood transfusions were given. When no improvement occurred and when deep hepatic coma persisted for 24-36 hours after the last exchange transfusion extracorporeal baboon liver perfusion was carried out.

Exchange transfusion was performed through a brachial arteriovenous Silastic shunt by using an improved, semiautomatic technique which is designed to maintain isovolaemia throughout the exchange (Abouna, 1971). For each full exchange 14-16 units of fresh (less than six hours old) heparinized blood were used. Three exchanges were carried out in each patient over a period of two to three days.

Liver perfusion was carried out by using a modification of the technique previously described, employing regional heparin:zation and a small and disposable perfusion circuitry requiring 250-300 ml of blood for priming (Abouna, 1968). The liver was aseptically removed from healthy baboons (Papio papio weighing $40-60 \mathrm{lb} ; 18 \cdot 1-27 \cdot 2 \mathrm{~kg}$ ); it was immediately cooled by perfusion with a chilled electrolyte solution (Abouna et al., 1971a) and then taken to the perfusion apparatus in the patient's room. Perfusion was started after 30-40 minutes of cold ischaemia and was maintained for a period of 13-16 hours without interruption.

During, before, and after each extracorporeal procedure a full biochemical and coagulation survey was carried out. Before and at intervals after treatment serum samples were drawn for measurement of haemagglutinins and lymphocytotoxins to baboon and human cells and of antibody to baboon serum proteins by standard laboratory techniques. Periodically, liver biopsy specimens were removed from both patients by needle aspiration.

\section{Case 1}

A 13-year-old girl was admitted to hospital with a two-week history of fever, malaise, and progressive jaundice. Acute viral hepatitis was diagnosed and she was started on the standard medical regimen, including $80 \mathrm{mg}$ of prednisone daily. Tests for Australia antigen were negative, but liver function tests indicated severe hepatic necrosis: serum total bilirubin $80 \mathrm{mg} / 100 \mathrm{ml}$; aspartate aminotransferase (SGOT) $3,200 \mathrm{mU} / \mathrm{ml}$; alkaline phosphatase 115 $\mathrm{mU} / \mathrm{ml}$; total protein $6.7 \mathrm{~g} / 100 \mathrm{ml}$ (albumin $1.3 \mathrm{~g}$ ); blood sugar $60 \mathrm{mg} / 100 \mathrm{ml}$; blood urea nitrogen (B.U.N.) $8 \mathrm{mg} / 100 \mathrm{ml}$; prothrombin concentration $24 \%$; clotting factor II $20 \%, \mathrm{~V} 20 \%$, VII $25 \%$, IX $10 \%$, and X $30 \%$ of normal. The patient was also known to have familial elliptocytosis and the very high serum bilirubin was thought to be partly due to a haemolytic crisis which was triggered by the hepatitis.

While on medical treatment she continued to deteriorate rapidly and by the 14th hospital day she became deeply comatose. An E.E.G. examination at this time showed greatly abnormal pattern with markedly diminished cerebral activity, predominant slow theta rhythm, and multiple spikes. Her medical attendants thought that prognosis was grave and recovery unlikely, and she was referred for treatment by exchange tranfusions. Three exchange transfusions during a period of three days resulted in pronounced clearing of bilirubin and temporary rise in clotting factors but without any objective clinical improvement. By the 18th hospital day she had become decerebrate and non-responsive and was bleeding from the gastrointestinal tract, and it was decided to treat her with baboon liver perfusion.

Perfusion was carried out the next day and was continued for $13 \frac{1}{2}$ hours. After six hours of perfusion spontaneous movement and normal reflexes returned. At the end of perfusion she was awake and answering questions. An E.E.G. examination at this time 
Effect of Baboon Liver Perfusions on' Coagulation System. Values before (I) and after (II) Perfusion. Note Rise in Level of Liver-dependent Clotting Factors after Perfusion which is Accompanied by a Fall in Blood Platelets

\begin{tabular}{|c|c|c|c|c|c|c|c|c|c|c|c|c|c|c|c|c|}
\hline \multirow[t]{2}{*}{ Case No. } & \multicolumn{2}{|c|}{ Prothrombin } & \multicolumn{2}{|c|}{$\begin{array}{r}\text { Platelets } \\
\times 10^{3}\end{array}$} & \multicolumn{2}{|c|}{$\begin{array}{l}\text { Fibrinogen } \\
\text { (mg/100 ml) }\end{array}$} & \multicolumn{2}{|c|}{$\begin{array}{c}\text { Factot II } \\
(\%)\end{array}$} & \multicolumn{2}{|c|}{$\underset{(\%)}{\text { Factor } \mathbf{V}}$} & \multicolumn{2}{|c|}{$\underset{(\%)}{\text { Factor VII }}$} & \multicolumn{2}{|c|}{$\underset{(\%)}{\text { Factor } \mathbf{X}}$} & \multicolumn{2}{|c|}{$\begin{array}{c}\text { Partial } \\
\text { Thromboplastin } \\
\text { Time } \\
\text { (Seconds) }\end{array}$} \\
\hline & I & II & I & II & I & II & I & II & I & II & I & II & I & II & $I$ & II \\
\hline$\frac{1}{2}$ & $\begin{array}{l}22 \\
10\end{array}$ & $\begin{array}{l}40 \\
50\end{array}$ & $\begin{array}{l}150 \\
165\end{array}$ & $\begin{array}{l}110 \\
115\end{array}$ & $\begin{array}{l}106 \\
154\end{array}$ & $\begin{array}{r}95 \\
144\end{array}$ & $\begin{array}{l}20 \\
45\end{array}$ & $\begin{array}{l}30 \\
55\end{array}$ & $\begin{array}{l}10 \\
30\end{array}$ & $\begin{array}{l}30 \\
45\end{array}$ & $\begin{array}{l}25 \\
35\end{array}$ & $\begin{array}{l}30 \\
45\end{array}$ & $\begin{array}{l}30 \\
20\end{array}$ & $\begin{array}{l}55 \\
60\end{array}$ & $\begin{array}{l}106 \\
400\end{array}$ & $\begin{array}{l}80 \\
99\end{array}$ \\
\hline
\end{tabular}

showed considerable improvement, and though normal alpha rhythm was not yet established, there was less slowing, the voltage was almost normal, and there were no spikes or sharp waves. During the next 12-24 hours she became fully conscious, asking for food and drink. Improvements in blood chemistry and blood coagulation after perfusion were equally striking (Fig. 1, Table). The next morning oral feeding with a low-protein diet was started and slowly increased so that by the end of the second week she was ambulant and taking $80 \mathrm{~g}$ of protein with a 3,600-calorie diet.

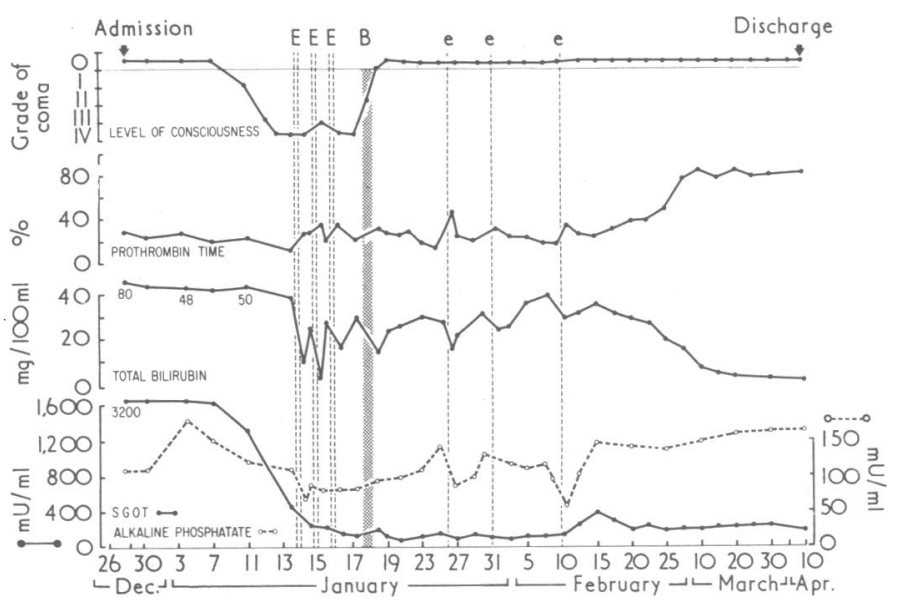

FIG. 1-Hospital course of Case 1. Three consecutive exchange transfusions (E) failed to produce clinical improvement. Normal consciousness was restored by a 13-hour baboon liver perfusion (B). Hepatic regeneration was active but functional recovery very slow. Supportive therapy was supplemented by intermittent "limited" exchange transfusions (e) for defective coagulation. Note the pronounced fall in bilirubin and rise in prothrombin concentration following perfusion and exchange transfusion.

However, adequate spontaneous hepatic regeneration was extremely slow. Substitution therapy with platelets, albumin, and intermittent small exchange transfusions was therefore maintained. Over the next few weeks spontaneous improvement in liver function was noted and was accompanied by a progressive fall in bilirubin and a sustained rise in prothrombin and in clotting factors. Supportive therapy was gradually discontinued and she was allowed to go home three and a half months after admission.

Liver biopsy performed two weeks after perfusion showed extensive hepatic necrosis, cholestasis, intense inflammatory reaction, and some fibrosis. However, signs of active liver cell regeneration were present, including binucleate cells and mitotic figures. Biopsy two months after treatment showed abundant chronic inflammatory cells, postnecrotic fibrosis, and other features of chronic active hepatitis. Biopsy at five months showed a more quiescent picture but with definite evidence of portal cirrhosis. Serial liver scans showed diminishing liver size and moderate splenomegaly. At the time of writing, eight months later, the patient was in excellent health and back at school. Her packed cell volume was $41 \%$, serum bilirubin $1.7 \mathrm{mg} / 100 \mathrm{ml}$, SGOT $100 \mathrm{mU} / \mathrm{ml}$, alkaline phosphatase $110 \mathrm{mU} / \mathrm{ml}$, total protein $7.5 \mathrm{~g} / 100 \mathrm{ml}$ (albumin $4 \cdot 2 \mathrm{~g}$ ), B.U.N. $7 \mathrm{mg} / 100 \mathrm{ml}$, serum creatinine $0.6 \mathrm{mg} / 100 \mathrm{ml}$, platelet count $287,000 / \mathrm{mm}^{3}$, and prothrombin $80 \%$ with normal coagulation profile.

\section{Case 2}

A 24-year-old housewife was admitted to hospital with one week's history of fever, jaundice, failing vision, and increasing confusion.
On admission she was drowsy but communicable and had an enlarged tender liver. Tests for Australia antigen were negative but liver function survey showed a severe degree of liver necrosis and profound defect in blood coagulation: serum total bilirubin $12 \mathrm{mg} / 100 \mathrm{ml}$; SGOT $7,200 \mathrm{mU} / \mathrm{ml}$; alkaline phosphatase 180 $\mathrm{mU} / \mathrm{ml}$; total protein $7.6 \mathrm{~g} / 100 \mathrm{ml}$ (albumin $2.8 \mathrm{~g}$ ); blood sugar $50 \mathrm{mg} / 100 \mathrm{ml}$; B.U.N. $7 \mathrm{mg} / 100 \mathrm{ml}$; fibrinogen level $123 \mathrm{mg} /$ $100 \mathrm{ml}$; prothrombin concentration $10 \%$; clotting factor II $10 \%$, V $10 \%$, VII $5 \%$, and X $8 \%$, with partial thromboplastin time of 250 seconds, control 72 seconds. A diagnosis of fulminant viral hepatitis was made and she was started on the standard medical regimen, including $120 \mathrm{mg}$ of prednisolone daily. Over the next 48 hours the level of consciousness rapidly deteriorated and grade IV hepatic coma supervened. Treatment was continued with exchange blood transfusions. After the first exchange some clinical improvement was noted but this was very transient. Two further exchanges were carried out over the next 36 hours without any clinical response (Fig. 2).

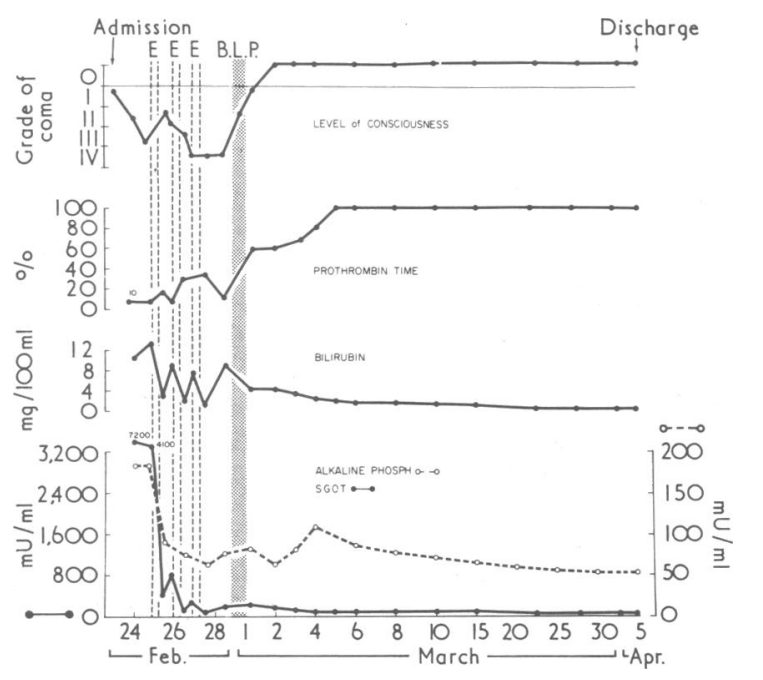

FIG. 2-Hospital course of Case 2. In spite of three consecutive exchange blood transfusions (E) hepatic coma persisted and became deeper. Consciousness was restored following a 16-hour baboon liver perfusion (B.L.P.). Liver cell regeneration was quite rapid and supportive therapy was safely discontinued within 14 days.

On the fourth hospital day her condition became critical with hypotension, oliguria, and decerebrate rigidity, and it was decided to treat her with baboon liver perfusion. This was carried out the next day and perfusion was successfully maintained for $16 \frac{1}{2}$ hours. During the first few hours of perfusion her circulatory state improved and her rigidity dramatically gave way to normal muscle tone and reflexes. By the 10th hour of perfusion she became restless and just before the end of perfusion she began to respond to her name and to verbal commands. Four hours later she was able to talk. The following morning she became fully conscious. Oral feeding with low-protein diet was begun and was increased to $100 \mathrm{~g}$ a day. The subsequent clinical and biochemical progress was fairly rapid (Fig. 2), so that within 14 days all substitution therapy was safely discontinued and she was discharged home six weeks after admission.

Liver biopsy one week after perfusion showed typical features of viral hepatitis in the acute phase with signs of very active liver cell regeneration. Liver biopsy at three months showed practically normal liver tissue. 
At the time of writing, seven months after treatment, she was in excellent health looking after her four children and working as a part-time waitress. Her P.C.V. was $42 \%$, platelet count 270,000 / $\mathrm{mm}^{3}$, total bilirubin $0.8 \mathrm{mg} / 100 \mathrm{ml}$, SGOT $50 \mathrm{mU} / \mathrm{ml}$, alkaline phosphatase $52 \mathrm{mU} / \mathrm{ml}$, total protein $7.6 \mathrm{~g} / 100 \mathrm{ml}$ (albumin 4.8 g), B.U.N. $9 \mathrm{mg} / 100 \mathrm{ml}$, serum creatinine $0.6 \mathrm{mg} / 100 \mathrm{ml}$, prothrombin time and coagulation factors $100 \%$.

\section{Discussion}

The results obtained in these patients show that while both exchange blood transfusions and liver perfusions resulted in a pronounced clearing of bilirubin, in neither patient was there any demonstrable clinical improvement after repeated consecutive exchanges. In contrast, perfusions with the baboon livers were successful in reversing deep grade IV coma in both patients. It was observed that the recovery of consciousness started during perfusion and became fully manifest within a few hours of terminating the procedure.

In addition to producing clinical recovery, these perfusions were followed by a pronounced rise in the level of liverdependent clotting factors (see Table), and though this was temporary, lasting 12-24 hours, we believe that such improvement is valuable in preventing bleeding complications. Synthesis of clotting factors also provides an important guide in assessing the quality and the clinical success of perfusion.

We used baboon livers in these patients because it was shown in an earlier study that the liver of this species could be made to function extracorporeally for up to 24 hours and that it was successful in reversing coma and in correcting serious abnormalities in biochemical function (Abouna et al., 1970). Though repeated porcine or bovine liver perfusions can sometimes produce a similar clinical improvement, the results have been generally inconsistent and perfusions very difficult to maintain for more than a few hours without serious complications (Parbhoo et al., 1971). The most serious of these complications has been the development of a bleeding diathesis during perfusion (Eiseman et al., 1965; Condon et al., 1970; Parbhoo et al., 1971). In addition, antipig serum antibody as well as clinical immunological reactions may develop when repeated pig liver perfusions are carried out, whereas neither clinical reaction nor antiserum antibodies develop when baboon livers are repeatedly used (Abouna et al., 1970). The superiority of the baboon liver in this respect is largely due to the much smaller degree of antigenic disparity between man and baboon than between man and pig; hence perfusions can be maintained for longer periods.

The results obtained in these two patients confirm these observations and show that prolonged perfusions with the isolated baboon liver are free from immunological and other complications and that these livers are indeed capable of carrying out the synthetic as well as the excretory functions of a normal liver for many hours. In our experience baboon liver perfusion has consistently resulted in reversal of deep hepatic coma on each of seven occasions during the treatment of four patients. Though the titre of the naturally occurring preformed antibody to baboon red cells and lymphocytes increased after perfusion, antibaboon serum antibody was never detected during the period of follow-up. Details of these and other immunological findings have been discussed elsewhere (Abouna et al., 1971b). We now believe that this procedure is probably the best available method of treatment for hepatic coma and that, with good techniques, extracorporeal baboon liver perfusions are safer, more practical, and more effective than cross-circulation with a whole baboon (Saunders et al., 1968; Hume et al., 1970) or cross-circulation with a human volunteer or with a human cadaver (Burnell et al., 1967; Benhamou et al., 1968; Summers, 1970; Winch, 1971).

Our experience in these and other patients shows that supportive management in acute hepatic failure does not end when the patient recovers consciousness and that ultimate patient survival depends largely on the degree of initial hepatic damage and on the rate of subsequent liver regeneration. For this reason successful treatment requires, in addition to liver perfusion, constant substitution therapy and a relentless effort in detecting and treating complications until liver regeneration becomes adequate to support life. Thus in Case 1 extensive hepatic necrosis had occurred and liver regeneration was extremely slow (Fig. 1) and intensive supportive therapy had to be maintained for nearly two months after her regaining normal consciousness. In addition to infusion of platelets, fibrinogen, cryoprecipitate, and fresh blood it was necessary to carry out intermittent "limited" exchange blood transfusions (5-6 units) whenever clotting factors reached a dangerously low level. Indeed, we believe that while exchange transfusions are of no value in reversing deep coma, they are valuable in correcting clotting defects.

During the treatment of patients with severe hepatic necrosis it is often difficult to determine the extent of supportive therapy required or to be able to predict the ultimate prognosis. Our observations indicate that frequent measurement of blood coagulation factors does provide a valuable guide in planning therapy and in assessing the rate of liver regeneration, and we agree with Davis et al. (1968) that periodic liver biopsy with needle aspiration is helpful in determining prognosis.

In conclusion, we believe that the results obtained in these patients are encouraging, and they show that successful treatment of acute hepatic coma, with ultimate patient survival, is possible by using extracorporeal baboon liver perfusion and that this form of hepatic support merits further clinical trials.

Supported by the United States Public Health Service grant PR-65 (General Clinical Research Centers Program). This work was made possible through the excellent care given to these patients by the nursing staff of the Clinical Research Center, Medical College of Virginia. We thank Dr. Ali Hussaini and the staff of the blood bank for constant laboratory support, and Dr. G. Costa for help and encouragement.

Requests for reprints should be sent to Dr. G. M. Abouna, Department of Surgery, Medical College of Georgia, Augusta. Georgia 30902, U.S.A.

\section{References}

Abouna, G. M. (1968). Lancet, 2, 1216.

Abouna, G. M. (1971). Surgery, Gynecology and Obstetrics with International bouna, G. M. (1971). Surgery, Gy

Abouna, G. M., Kirkley, J. R., Hull, C. J., Ashcroft, T., and Kerr, D. N. S. (1969). Lancet, 1, 64.

Abouna, G. M., Serrou, B., Boehmig, H. G., Amemiya, H., and Martineau, G. (1970). Lancet, 2, 391 .

Abouna, G. M., Koo, C. G., Howanitz, L. F., Ancarani, E., and Porter, K. A. (1971a). Transplantation Proceedings, 3, 650.

Abouna, G. M., et al. (1971b). Transplantation Proceedings. In press.

Benhamou, J. P., Rueff, B., and Sicot, C. (1968). Revue Franfaise d'Études Cliniques et Biologiques, 13, 651.

Berger, R. L., et al. (1966). New England fournal of Medicine, 274, 497.

Burnell, J. M., Dawborn, J. K., Epstein, R., Gutman, T. A., and Leinbach, G. E. (1967). New England fournal of Medicine, 276, 935.

Condon, R. E., Bombeck, C. T., and Steigmann, F. (1970). American fournal of Surgery, 119, 147 .

Fournal of Surgery, 119, 147 .
Davis, M. A., Peters, R. L., Pedekar, A. G., and Reynolds, T. B. (1968). New England fournal of Medicine, 278, 1248

Eiseman, B., Liem, D. S., and Raffucci, F. (1965). Annals of Surgery, 162, 329.

Hume, D., Gayle, W., and Williams, G. (1969). Surgery, Gynecology and Obstetrics with International Abstracts of Surgery, 128, 495.

Jones, E. A., Clain, D., Clink, H. M., MacGillvary, M., and Sherlock, S. (1967). Lancet, 1, 169.

Parbhoo, S. P., et al. (1971). Lancet, 1, 659.

Saunders, S. J., et al. (1968). Lancet, 2, 585.

Starzl, T. E., Marchioro, T. L., and Faris, T. D. (1966). American fournal of Surgery, 112, 391 .

Summers, R. W., Curtis, S. J., Hartford, C. E., and Rubush, J. L. (1970). Fournal of the American Medical Association, 214, 2297.

Williams, R. (1971). British Medical fournal, 1, 213.

Willams, R. (1971). British Medical fournal, 1, 216. 